\title{
Перспективні підходи до вивчення стану здоров'я сучасних школярів та шляхи його поліпшення
}

\section{С. В. Красножон}

\author{
Донецький національний медичний університет ім. М. Горького, Донецьк, Україна
}

\begin{abstract}
Резюме. Статья посвящена разработке принципов распределения школьников на медицинские группы для занятий физическим воспитанием. Приведено обоснование новой методологии и методики распределения школьников на группы с учетом уровня здоровья и показателей физической работоспособности. В результате исследований установлено, что обследуемый контингент (школьники, отнесенные к основной медицинской группе для занятий физической культурой), неоднороден по уровню физического здоровья и подлежит дифференцированию по пяти функциональным группам здоровья.

Ключевые слова: уровень здоровья, состояние здоровья, школьники, медицинское обеспечение, адаптация к физическим нагрузкам, физическое воспитание.
\end{abstract}

Summary. Article is devoted to the development of principles for the distribution of medical students groups for physical education classes. The rationale for a new methodology and allocation methodology students into groups for physical exercise, taking into account the level of health and physical performance. The studies found that students assigned to basic medical group for physical culture, which is traditionally considered healthy, are not homogeneous in terms of physical health and are subject to differentiation by five functional groups of health.

Key words. Health level, health, school, medical care, adaptation to physical activity, physical education.

Постановка теми. Проблема збереження та зміцнення здоров'я дітей була і залишається однією з актуальних у сучасній медицині. Особливо гостро вона відчувається на тлі критично низького рівня стану здоров'я популяції та у зв'язку з демографрічною кризою, що зберігається в Україні [4]. Погіршення показників рівня здоров'я фахівці пов'язують з екологічною ситуацією, зниженням рівня соціальної та медичної культури населення, а також 3 недостатніми можливостями методики оцінки стану здоров'я дітей на донозологічному етапі. Лікарями найчастіше використовуються антропометричні та деякі лабораторні показники, які дають можливість стверджувати, що на момент обстеження в конкретної дитини немає гострих проявів хвороби або активності хронічних захворювань. Існуюча методика не відображає адаптацію організму дитини до фрізичного навантаження $\mathrm{i}$ тим паче не дозволяє прогнозувати імовірність виникнення хронічних захворювань [6].

Організм дитини характеризується специфрічними особливостями будови, біохімічних процесів і функцій в цілому, а також окремих органів, які зазнають якісних (розвиток) та кількісних (зростання) змін на різних етапах його життя. При нормальному розвитку дитини обидва ці процеси тісно взаємопов'язані, але мають гетерохроний (і навіть реципрокний) характер, що не враховується у ході оцінювання фрізичного розвитку за антропометричними показниками [4]. Виняткова роль в онтогенезі людини належить скелетним м'язам. Рівень енерговитрат в стані спокою і відповідний їм рівень різних систем організму визначаються особливостями функціонування скелетних м'язів у різні вікові періоди (починаючи з антенатального). Тобто індивідуальний розвиток організму протягом життя пов'язаний з віковими змінами скелетних м'язів $[2,7]$. Встановивши провідну роль скелетної мускулатури, яка регулюється діяльністю відповідних нервових центрів, І. А. Аршавський (1972) сорормулював енергетичне правило скелетних м'язів, фрізіологічний сенс якого полягає у тому, що рухова активність живої системи є чинником функціональної індукції надлишкового анаболізму. Причому надлишковий анаболізм має місце не тільки в скелетних м'язах, але також в органах і системах, що забезпечують функцію руху (серцево-судинна, дихальна, ендокринна системи тощо). Таким чином, ріст і розвиток $\epsilon$ природним наслідком активності живої системи та її елементів, а м'язова діяльність - основною умовою розумової та фрізичної працездатності [6]. 
Величина максимального споживання кисню (МСК) - один з головних показників у фрізіології м'язової діяльності. Фізіологічне значення МСК $€$ відображенням сумарної пропускної здатності усіх механізмів транспорту кисню - від транспорту газів у легенях до транспорту електронів у мітохондріях скелетно-м'язових волокон. А оскільки швидкість поглинання кисню пропорційна потужності роботи, яка може виконуватися за цей рахунок, величину МСК називають ще «аеробною продуктивністю». Таким чином, основним критерієм здоров'я (життєздатності) слід вважати величину МСК даного індивіда. Саме МСК - кількісна ознака рівня здоров'я, показник «кількості» здоров'я, тому що аеробні здатності $€$ відображенням на організменому рівні фрункцій мітохондрій [4]. Саме МСК - критерій неспецифрічної стійкості організму під час дії на нього різноманітних стрес-фракторів від проникаючої радіації до гострої гіпоксії. Величина МСК, віднесена до одиниці маси тіла, ймовірно, - єдиний показник, що залишається незмінним протягом тривалого часу (від 5 до 40 років). Найменше відхилення від нормального розвитку, хвороба, інволютивні процеси все це відразу позначаються на динаміці цього показника $[4,8]$. Відносна величина МСК є критерієм розподілу здорових і хворих осіб на різні рівні фрізичного здоров'я, в основі яких лежить, як випливає з самої суті показника, обсяг резервів біоенергетики [3].

Провідну роль у вирішенні завдання збереження й зміцнення здоров'я молодого покоління, корекції й відновлення порушених функцій, оздоровлення й профрілактики захворювань, безперечно, відіграє фрізична культура. Однак, на думку багатьох авторів, оздоровча ефективність шкільної фрізичної культури в останні роки знизилася [1]. Більш того, заняття фрізкультурою в загальноосвітніх установах вимагають складання нормативів, однакової форми проведення, а відсутність системи об'єктивної оцінки рівня здоров'я, а звідси й ефективності занять знижують мотивацію учнів і навіть формують негативне ставлення до фрізичної культури в цілому [5]. 3 кожним роком збільшується кількість випадків несподіваної смерті на уроках фрізичної культури на спортивних майданчиках шкіл України й Росії [4]. Діти помирають на уроках фрізкультури при повному, здавалося б, здоров'ї. За даними медичних оглядів, їх було віднесено до І групи здоров'я, тобто до основної медичної групи. Згідно з офіційними інструкціями, вони навчались фрізичних вправ без необхідних для них обмежень, отримували заліки за нормативами фрізичної підготовленості та навіть мали можливість займатися багатьма видами спорту.

У нашій країні при оцінюванні індивідуального здоров'я для занять фрізичними вправами використовують методику розподілу дітей на п'ять стандартних груп здоров'я за С. М. Громбахом, (1973). При цьому не враховують дані про фрункціональні резерви й адаптацію до фрізичного навантаження [5]. Пропоноване нормативними документами застосування проби Руф'є під час медичних оглядів не вирішує, а навіть ускладнює задачу розподілу учнів на групи здоров'я для занять фрізкультурою. Причина проблем із застосуванням проби Руф'є як методу діагностики фрункціонального стану серцево-судинної системи дітей - ігнорування віку дитини при обчисленні індексу Руф'є (Апанасенко, Міхалюк, Заневський, 2011).

Виходячи з несприятливого положення, що створилося зі здоров'ям і малою оздоровчою ефективністю фрізичного виховання, його небезпекою для життя й здоров'я школярів, актуальною $€$ розробка принципів розподілу школярів на медичні групи для занять фрізичним вихованням шляхом оцінки їхнього фрізичного здоров'я й адаптаційних можливостей на основі простих і раціональних діагностичних систем.

Мета та завдання дослідження. Обгрунтувати критерії розподілу школярів на групи для занять фрізичними вправами, дотримуючись принципів безпеки для життя й здоров'я, шляхом клініко-фрізіологічного порівняння функціональних резервів груп здоров'я, визначених за різними алгоритмами.

Об'єкт дослідження - медичне забезпечення фрізичного виховання в умовах загальноосвітньої школи.

Предмет дослідження - рівень здоров'я та фрізичної працездатності школярів основної медичної групи.

Методи дослідження: теоретичний аналіз і узагальнення спеціальної літератури, оцінка здоров'я досліджуваної групи школярів за С. М Громбахом, рівня фрізичного здоров'я за методикою Г. Л. Апанасенко й В. А. Шаповалової, дослідження анамнезу життя й сімейного анамнезу, аналіз рівня рухової активності дітей протягом доби, фрізичного розвитку, здатності адаптації організму школярів до фрізичного навантаження за даними фрункціональних проб і електрокардіограсрії, аналіз гострої захворюваності вибраної групи школярів протягом навчального року, методи математичної статистики.

Результати дослідження та їх обговорення. Проведено аналіз існуючих вітчизняних та 
іноземних методик оцінки рівня здоров'я дітей та підлітків (методика кількісної експрес-оцінки рівня ффізичного здоров'я за Г. Л. Апанасенком; комп'ютерна програма FITNESSGRAM/ ACTIVITYGRAMM, що розроблена Інститутом Купера та Національною асоціацією спорту і фрізичного виховання США (NASPE); компьютернодіагностична програма контролю здоров'я школярів, розроблена М. П. Горобеєм; комп'ютерна програма, запропонована С. В. Хрущовим, С. Д. Поляковим, А. М. Соболєвим на основі експрес-оцінки рівня фрізичного здоров'я Г. Л. Апанасенко; автоматизована система оцінки рівня фрізичного здоров'я «Школяр» В. А. Шаповалової та ін.). 3 цих методик відібрано для дослідження методику «Кількісної експрес-оцінки рівня фрізичного здоров'я» за Г. Л. Апанасенком як таку, що відповідає поставленим цілям роботи.

Із загальної кількості школярів $10-12$ років для дослідження було відібрано дітей, які віднесені за результатами медичного огляду за методикою С. М. Громбаха (в міській поліклініці) до основної медичної групи в кількості 139 чоловік $(61,8$ \% загальної кількості школярів даного віку). Дані, отримані під час виконання роботи, свідчать про те, що до основної медичної групи увійшли школярі з різним рівнем фрізичного здоров'я, яким на уроках із фрізичного виховання було пропоновано виконувати однакове фрізичне навантаження.

При проведенні дослідження за методикою Г. Л. Апанасенко з'ясувалося, що високий рівень фрізичного здоров'я мають лише $5 \%$ досліджених школярів, рівень фрізичного здоров'я вище середнього - у 6,2 \%, середній - у 22,2 \% та нижче середнього - у 26,4 \% обстежених. Найбільша кількість учнів мала низький рівень здоров'я - 40,2 \%. Тобто до безпечної зони здоров'я відносяться лише 11,2 \% школярів, які брали участь в дослідженні $(10,5 \%$ дівчат та $12,2 \%$ хлопців).

Аналіз інформативності отриманих результатів (як за літературними, так і за отриманими нами даними) показує: в основі методики Г. Л. Апанасенко висловлено думку про те, що підвищення життєздатності живої системи супроводжується зростанням енергопотенціалу, про що можна судити за збільшенням резервів функції та їх економізації (Апанасенко, 1987). Тобто рівень здоров'я, за методикою Г. Л. Апанасенка супроводжується збільшенням резервів основних функцій. Це добре корелює із показниками, що характеризують функціональний стан та адаптацію до фрізичних навантажень дітей і підлітків. При цьому, чим вище рівень здоров'я, тим краще показники функцій обстежених. Індекс Робінсона, Руф'є, ЧСС, за цією методикою, має високі кореляційні зв'язки з рівнем здоров'я ( $p<0,05)$.

Існуюча система розподілу школярів на медичні групи для занять фрізичною культурою не дозволяє здійснювати фрізичне виховання диференційовано в залежності від стану функціональних систем і адаптаційних можливостей зростаючого організму. Задачу про розподіл учнів на групи здоров'я для занять фрізкультурою за результатами проби Руф'є не розв'язано, а наказ, що регламентує медичним працівникам її застосування, помилковий, бо не враховує вік пацієнта. Таким чином, від класичної проби Руф'є як методу розподілу учнів за групами здоров'я для занять фрізкультурою пропонуємо відмовитися. Вважаємо за доцільне оцінюванювати результати й фрізичного навантаження за часом відновлення пульсу після 30 присідань за 45 с залежно від рівня фрункціональної готовності організму дитини. Саме в такій редакції надано експрес-систему оцінки рівня здоров'я в підручнику з санології (Апанасенко, Попова и др., 2011).

Підтвердженням необхідності використання саме методики Г. Л. Апанасенка для вирішення поставлених на початку роботи питань $\epsilon$ проведені визначення рівня рухової активності, ЕКГ-дослідження та аналіз гострої захворюваності протягом навчального року.

Вимірювання рухової активності проводилося за Фремінгемською методикою. Кількісний аналіз добової рухової активності підтверджує дані літератури про більш високі показники індексу рухової активності (IPA) у хлопців в кожній із досліджуваних вікових груп. Якісний аналіз IPA свідчить про збільшення цього показника у віці 11 років - як у хлопців, так і у дівчат - в порівнянні 3 віковими групами 10 та 12 років, в яких IPA вищий у хлопців, а в 11 років дівчата за цим показником випереджають хлопців.

Відмічено значне збільшення IPA в той день, коли в розкладі занять $\epsilon$ фрізична культура. Причому, з урахуванням уроку з фрізичного виховання, в 11 років IPA також більше зріс в дівочій групі, ніж у хлопців (рис. 1).

В 10-11 років протягом доби рухова активність школярів переважно прирівнюється до малого рівня рухової активності, за винятком дня, коли в розкладі занять $€$ фрізична культура. В віковій групі 12 років діти переважно виконують рухи, віднесені до сидячого рівня рухової активності за рахунок виконання роботи, пов'язаної з допомогою батькам у домашньому господарстві та усвідомлених занять самостійно (рис. 2). 
Рисунок 1 - Дінаміка індексу рухової активності у школярів обох статей у віковій групі $10-12$ років.

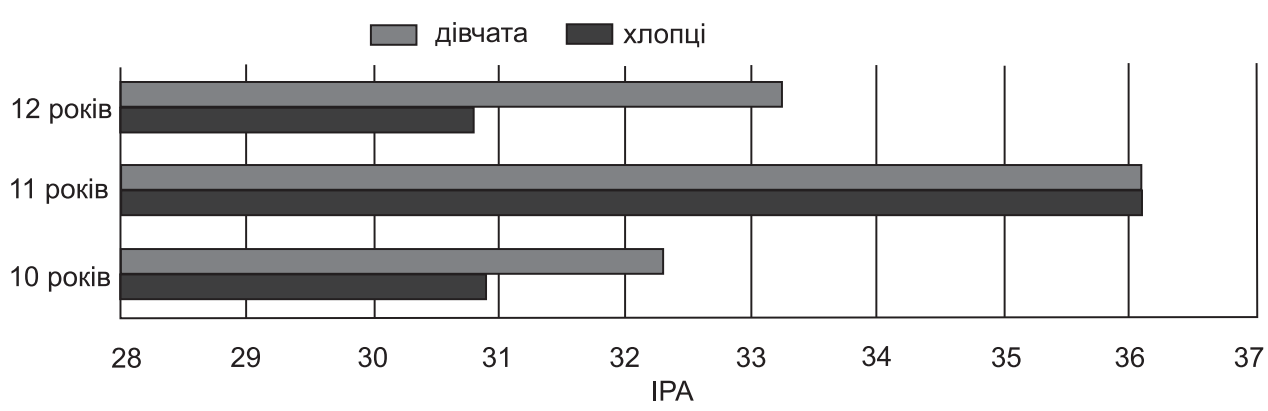

Залежність рівня фрізичного здоров'я, за Г. Л. Апанасенком, від рівня рухової активності (IPA) у школярів 10-12 років основної медичної групи має такий вигляд:

$\begin{array}{lcc} & \text { Хлопці } & \text { Дівчата } \\ \text { Низький } & 32,4 & 34,1 \\ \text { Нижче середнього } & 36,3 & 34,6 \\ \text { Середній } & 37,2 & 35,6 \\ \text { Вище середнього } & 37,8 & 41,6 \\ \text { Високий } & 40,5 & 41,9\end{array}$

Аналіз отриманих даних свідчить про зростання рівня рухової активності при збільшенні рівня фрізичного здоров'я. Ця тенденція спостерігається в групі і хлопців, і дівчат. Незалежно від рівня фрізичного здоров'я у групі дівчат показник рівня рухової активності вищий, ніж у групі хлопців, ймовірно за рахунок участі дівчат у веденні домашнього господарства (прибирання, миття посуду тощо). Наочно ці відмінності ілюструє рисунок 3 , який показує, що для підтримки оптимального рівня здоров'я необхідне збільшення рухової активності.

Статистичний аналіз результатів рівня добової активності школярів з різним фрізичним здоров'ям показав достовірні розходження між результатами, отриманими у школярів вікової групи 10 та 11 років $(p=0,0001), 11$ та 12 років $(p=0,0016)$.

Аналізуючи електрокардіограму виділеної групи школярів, ми виявили зміни на ЕКГ у $66,2 \%$ обстежених школярів. У зв'язку з тим, що всі виявлені зміни на ЕКГ $\epsilon$ особливостями дитячої кардіограми, нікому із школярів не рекомендоване додаткове обстеження. Статистичний аналіз результатів ЕКГ-обстеження школярів показав достовірні розходження між групами вище середнього і низького рівнів здоров'я $(p<0,05)$.

Під час аналізу результатів тесту фрізичної працездатності школярів досліджуваної групи бачимо, що зі зростанням рівня фрізичного здоров'я збільшується абсолютний показник

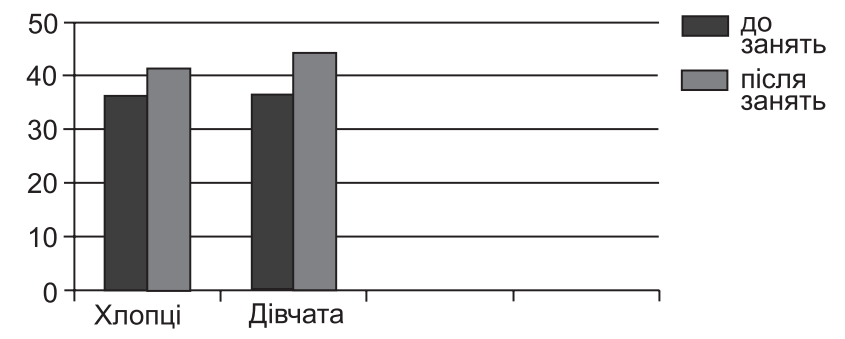

Рисунок 2 - Збільшення індексу рівня рухової активності школярів у віковій групі 11 років з урахуванням уроку фрізичного виховання

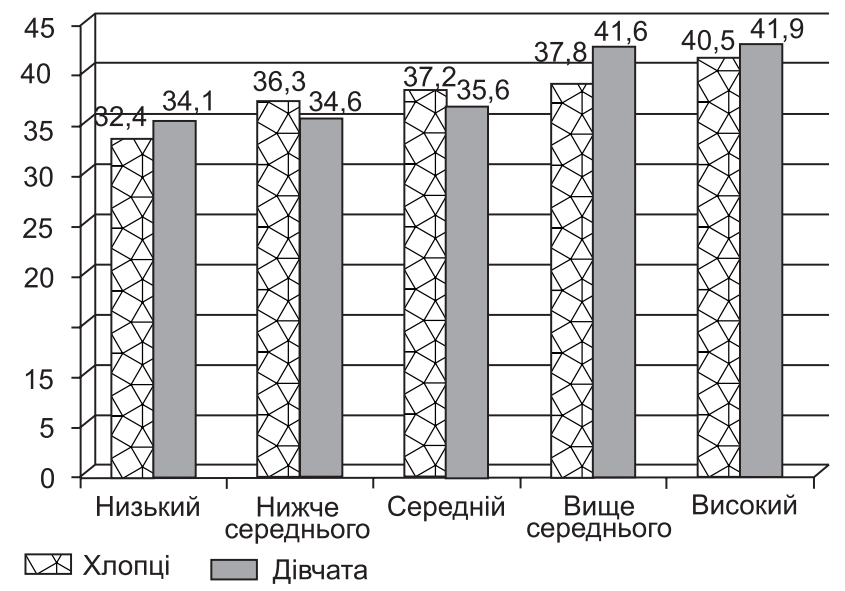

Рисунок 3 - Дінаміка рухової активності залежно від рівня фрізичного здоров'я.

максимально досягнутої потужності (МДП) при виконанні тесту PWC ${ }_{170}$. Середній показник МДП у школярів, яких віднесено до «безпечної зони здоров'я», становить $2,51 \pm 0,05$, а у школярів, які не увійшли до цієї групи, він дорівнює $1,57 \pm 0,1$. Статистичний аналіз результатів обстеження школярів з різними рівнями фрізичного здоров'я показав достовірні розходження між групами з БРЗ і НР3 ( $<<0,05)$.

Аналіз гострої захворюваності досліджуваної групи школярів протягом року показав, що дані про захворюваність у школярів з «безпечної» зони здоров'я, за Г. Л. Апанасенко, складають 8,95 \% загальної захворюваності (12 
випадків), ускладнень та хронічних захворювань не зареєстровано. Значно більше випадків захворювань в групах з середнім, нижче середнього та низьким рівнями здоров'я - загалом це 122 випадки захворювань $(87,8$ \%). Із збільшенням рівня фрізичного здоров'я школярів захворюваність знижується досить суттєво - на 54,7 \% в групі з рівнем здоров'я нижче середнього та на 97,4 \% - в групі з високим рівнем. Аналізуючи захворюваність школярів різної статі, бачимо, що в групі з низьким рівнем фрізичного здоров'я дівчата хворіли в 3,4 раза частіше, ніж хлопці.

Кратність випадків захворювання становить 1,7. Середня тривалість одного випадку захворювання в групі «безпечного рівня» здоров'я дорівнює 3,5 дня. В групі школярів з середнім, нижче середнього та низьким рівнями здоров'я захворювання триває 8,6 дня. Тривалість захворювання у хлопців та дівчат суттєво не відрізняється. Ускладнені форми (12 випадків - 8,95 \% загальної кількості захворювань) зареєстровані в групах з середнім, нижче середнього та низьким рівнями здоров'я. Цей показник дорівнює відповідно - 8,7, 33 та 58,3 \%. Кількість випадків ускладнень між школярами обох статей розподілено приблизно однаково. В обстеженій групі школярів вперше встановлених хронічних захворювань не зареєстровано. Достовірні відмінності були виявлені між групами школярів, яких віднесено до низького та високого рівнів фрізичного здоров'я в кожному віці: $t=4,23$, $\mathrm{p}<0,05$.

Таким чином, аналіз отриманих результатів та порівняння різних методик оцінки рівня здоров'я дітей і підлітків переконує в безсумнівній перевазі методики Г. Л. Апанасенко.

\section{Висновки}

1. Школярі основної медичної групи занять фрізичною культурою суттєво відрізняються за різними методиками за рівнем фізичного здоров'я. Контингент дітей, віднесених до основної медичної групи, яких традиційно вважають здоровими, не $є$ однорідним за рівнем фрізичного здоров'я та підлягає диференціюванню за пятьма фрункціональними групами здоров'я.

2. Порівняння методик оцінки рівня здоров'я дітей і підлітків переконує в безсумнівній перевазі методики Г. Л. Апанасенко. Виходячи 3 отриманих та проаналізованих результатів досліджень пропонуємо як критерій для розподілу школярів на групи для занять фрізичними вправами, дотримуючись принципів безпеки для життя й здоров'я, використовувати «Методику кількісної експрес-оцінки рівня фрізичного здоров'я дітей та підлітків» за Г. Л. Апанасенком та впровадити застосування в практику цієї технології.

3. Від класичної проби Руф'є як методу розподілу учнів за групами здоров'я для занять фрізкультурою пропонуємо відмовитися. Вважаємо за доцільне використання оцінки результатів фрізичного навантаження у вигляді часу відновлення пульсу після 30 присідань за 45 с, який залежить від рівня функціональної готовності організму дитини.

\section{Рекомендації}

1. Враховуючи взаємозв'язок між рівнем фрізичного здоров'я, функціональним станом організму школярів, рівнем фрізичної працездатності, рухової активності та тривалістю захворювань протягом року при регламентації фрізичного навантаження під час уроків фрізичного виховання рекомендується як критерій при розподілі на медичні групи використовувати методику кількісної експрес-оцінки рівня фрізичного здоров'я (Апанасенко Г. Л.).

2. Проводити розподіл школярів для занять фрізичним вихованням на три групи:

1) з низьким та нижче середнього рівнем фрізичного здоров'я;

2) з середнім рівнем фрізичного здоров'я;

3) з вище середнього та високим рівнем фрізичного здоров'я, тобто віднесені до «безпечної» зони здоров'я.

3. Школярі з низьким та нижче середнього рівнем фрізичного здоров'я потребують поглибленого медичного обстеження (для виключення патологічного процесу) та ретельного аналізу ендогенних фракторів ризику виникнення захворювань, їх усунення, індивідуального підходу під час занять фрізичним вихованням, проведення обов'язкових профрілактичних заходів, в тому числі сезонних.

4. Школярі з середнім рівнем здоров'я потребують проведення комплексу фрізкультурнооздоровчих та профрілактичних заходів протягом року в своїй групі.

5. Школярі з рівнем фрізичного здоров'я вище середнього та високим можуть та повинні регулярно займатися фрізкультурою та, за бажанням, спортом (з віковими обмеженнями). Спеціальних профілактичних заходів до школярів цієї групи не проводиться, тільки загальні профрілактичні в класі, школі чи регіоні. Школярів цієї групи відносять до «безпечної» зони здоров'я.

6. До основної групи для занять фрізичним вихованням повинні бути віднесені діти, що входять до «безпечної зони» здоров'я. Школярі основної групи, за С. М. Громбахом, але які не ввійшли до «безпечної зони», мають бути віднесені до підготовчої групи. 


\section{Література}

1. Альбицкий В. Ю. Заболеваемость детей и инвалидность / В. Ю. Альбицкий, Д. И. Зелинская, Р. Н. Терлецкая // Рос. пед. журн. - 2008. - № 1. - С. 32--35.

2. Апанасенко Г. Л. Санологія (Медична валеологія): навч. посіб. / Апанасенко Г. Л., Попова Л. О. - К.: Здоров'я, 2011. - 248 с.

3. Апанасенко Г. Л. Эволюция биоэнергетики и здоровье человека / Г. Л. Апанасенко. - СПб.: Петрополис, 1992. - 123 c.

4. Баранов А. А. Состояние здоровья современных детей и подростков и роль медико-социальных факторов в его фрормировании / А. А. Баранов, В. Р. Кучма, Л. М. Сухарева // Вестн. Рос. АМН. - 2009. - № 5. - С. 6-11.

5. Валеологічний інструментарій апаратно-програмної діагностики й моніторингу здоров'я: метод. посіб.; за ред. Гончаренко М. С.- Х.: ХНУ ім. В.Н. Каразіна, 2012. - 148 с.

6. Громбах С. М. Оценка здоров'я детей и подростков при массовых осмотрах / С. М. Громбах // Вопр. охраны материнства и детства. - 1973. - № 7. - С. 3-7.

7. Даниленко Г. М. Внутрішня картина здоров'я як системоутворююча складова активно-конструктивної профрілактики неінсрекційних захворювань школярів / Г. М. Даниленко // Гігієна населених місць. - 2006. Вип.48. - С. 462-467.

8. Маковкіна Ю. А. Своєчасна діагностика здоров'я дітей: оцінка адаптаційних можливостей / Ю. А. Маковкіна, Л. В. Квашніна / / Мистецтво лікування. - 2005. - № 10. C. $28-30$.

\section{References}

1. Albitskiy V. Yu. Children diseases and physical inability / V. Y. Albitskiy, D. I. Zelinskaya, R. N. Terletskaya // Rus. ped. Journal. - 2008. - N 1. - P. 32-35.

2. Apanasenko G. L. Sanology. (Medical valueology) / G. L. Apanasenko, Popova L. O. - Kiev: Zdorovya; 2011. 248 p.

3. Apanasenko G. L. Evolution of bioenergetics and health of the person. - St.-Petersburg: Petropolis; 1992. - $123 \mathrm{p}$.

4. Baranov A. A. The health State of children and teenagers and a role of medikal and social factors in its formation / A. A. Baranov, V. R. Kuchma, L. M. Suhareva // Bulletin of Russian AMS. - 2009. - N 5. - P. 6-11.

5. Valeology instrument of apparat and programm diagnostic and health monitoring: methods texbook; ed. M. S. Goncharenko. - Kharkiv: Kharkov Nat. Univ. of V. N. Karazina, 2012. - 148 p.

6. Grombah S. M. The Estimation of children and teenagers health at mass control / S. M. Grombah // Questions of protection of motherhood and the childhood. - 1973. N 7. - P. 3-7.

7. Danilenko G. M. The internal health state as system created part of active and constructive prevention nonintectional diseases of pupils / G. M. Danilenko // Hygiene for the occupied places. - 2006. - N 48. - P. 462-467.

8. Makovkina $Y$. A. Timely diagnostics of children health: an estimation of adaptable possibilities / Y. A. Makovkina, L. V. Kvashnina // Treatment Art. -2005. - N 10. - P. 2830 . 